\section{spectā}

Journal of Photography

Arts, and Media

\title{
STRATEGI KREATIF ROY GENGGAM DALAM PEMOTRETAN IKLAN
}

\author{
Willy Pamungkas
}

Kurniawan Adi Saputro*

Kusrini**

Fakultas Seni Media Rekam, Institut Seni Indonesia Yogyakarta

Surel : kurniawan.as@isi.ac.id

Volume 1 Nomor 2,

November 2017: 103-110

\begin{abstract}
Abstrak
Anak-anak adalah objek yang dapat dieksplorasi dengan berbagai macam aspek dan pendekatannya dalam pemotretan. Setiap fotografer memiliki cara tertentu dalam memotret anak-anak, karena mereka memiliki perilaku yang susah diatur dan suasana hati yang mudah berubah. Seperti halnya Roy Gajah Seto Genggam Nusantoro atau dikenal sebagai Roy Genggam, fotografer dengan banyak pengalaman ini mempunyai cara tertentu dalam memotret anak-anak. Salah satu pemotretan iklan yang melibatkan anak-anak sebagai peduduk, adalah iklan Cussons pada 2014 dan 2016. Penelitian ini dilakukan untuk mengetahui strategi kreatif Roy Genggam dalam pemotretan iklan Cussons. Metode wawancara serta studi dokumen dan arsip, digunakan dalam mengumpulkan data-datanya. Data yang didapat, dianalis dan dikaitkan dengan teori lalu disajikan secara deskriptif atas fakta-fakta yang ditemukan. Hasil penelitian ini menunjukkan bahwa ada 12 cara yang dilakukan Roy Genggam serta tim RGP (Roy Genggam Photography) dalam memotret anakanak. Roy Genggam juga menggunakan tiga strategi kreatif dalam pemotretan iklan Cussons, yaitu strategi anak-anak sebelum pemotretan, strategi anak-anak saat pemotretan dan strategi hasil foto. Ketiga strategi tersebut terbentuk dari nalurinya dalam menghadapi masalah saat mewujudkan harapan-harapannya dalam pemotretan iklan Cussons.
\end{abstract}

Kata kunci: strategi kreatif, Roy Genggam, fotografi, anak-anak

\begin{abstract}
Roy Genggam's Creative Strategy in Advertising Photoshoot. Children are objects that can be explored by various aspects and approaches in photography. Each photographer has a particular way of photographing children, because children have unmanageable behavior and moreover they have mood swings. Just as Roy Gajah Seto Genggam Nusantoro, also known as Roy Genggam, has a particular way of photographing children. It is also due to Roy Genggam's rich experience in advertising photography involving children as sitters, one of which is photographing an advertisement for Cussons product in 2014 and 2016. In connection with this, a research is conducted to find the creative strategies in Roy Genggam's Cussons ad photoshoot. Methods used are interviews, studies of documents and records to collect data. The data retrieved, analyzed and linked with the theory and then presented descriptively on the found facts. The results of this study indicate that there are 12 ways Roy Genggam and his team do in overcoming the constraints that are typical for children during Cussons ad photoshoot. Roy Genggam also uses three creative strategies in Cussons advertising photography; the strategy for children before photographing, strategy for children while photographing and strategy of the photos result. Those strategies are formed by his own intuition in facing problems while he is trying to actualize his expectations in Cussons ad photoshoot.
\end{abstract}

Keywords: Roy Genggam, creative strategy, photography, children

\footnotetext{
${ }^{*}$ Dosen di Pascasarjana ISI Yogyakarta.

${ }^{*}$ Dosen di Program Studi Fotografi, Jurusan Fotografi, Fakultas Seni Media Rekam, ISI Yogyakarta.
} 


\section{PENDAHULUAN}

Setiap orang perlu memiliki kreativitas dalam menekuni bidang tertentu. Selalu ada cara bagaimana seseorang berkreativitas. Seperti halnya seseorang yang memilih dan menekuni bidang fotografi sebagai media berolah kreativitas. Bachtiar dalam Genggam (2015:44) menjelaskan, ruang kreatif yang disediakan fotografi begitu luas, beragam, dan cukup mampu mewadahi gagasan, ide, atau apa pun yang berhubungan dengan hidup dan kehidupan. Di dalam kehidupan, fotografi hadir dalam berbagai bentuk, format, jenis, subjek dan karakter serta gaya penampilan yang beraneka ragam (Soedjono, 2007:25). Setiap penampilan karya fotografi memiliki makna dalam kehadirannya yang memang berbeda tujuan dan keberadaannya. Soedjono (2007:30) menjelaskan, karya fotografi memiliki makna ekonomis bila karya tersebut menjadi produk komoditas yang bernilai karena diorientasikan bagi pencapaian tujuan komersial. Salah satu genre fotografi yang karyanya memiliki nilai ekonomis terlihat pada fotografi komersial di mana foto digunakan sebagai bentuk media iklan.

Fotografi sebagai media visual merupakan salah satu media iklan yang perkembangannya begitu pesat hingga saat ini. Semakin kuatnya pasar nasional maupun internasional, cenderung meningkatkan penggunaan fotografi sebagai media komunikasi dalam menawarkan suatu produk atau jasa. Hal itu terbukti dalam kehidupan manusia sehari-hari di mana sering dijumpai iklan pada papan iklan besar di jalan tol dan jalan-jalan besar pusat kota, begitu pun ketika seseorang membaca surat kabar atau majalah yang di dalamnya terdapat banyak foto yang bertujuan untuk menawarkan produk atau jasa. Selain itu, fotografi juga bisa menarik minat konsumen, hal ini terbukti fotografi digunakan pada suatu desain poster atau brosur. Soedjono
(2007:28) menambahkan, media iklan cetak sangat banyak memanfaatkan karya fotografi dengan berbagai bentuk dan subjeknya. Hal tersebut dimanfaatkan beberapa fotografer untuk menekuni bisnis fotografi di bidang fotografi komersial, salah satunya Roy Gajah Seto Genggam Nusantoro atau dikenal dengan sebutan Roy Genggam.

Roy Genggam adalah salah seorang fotografer di Indonesia yang sudah terkenal di kalangan penggiat fotografi di Indonesia. Sejak 1990 ia menekuni fotografi komersial dan sering menerima tawaran pemotretan iklan oleh produk-produk ternama. Cussons merupakan salah satu dari sekian banyak produk ternama yang pernah ia kerjakan yang model/sitter/peduduknya adalah anak-anak.

Manusia adalah objek yang dapat dieksplorasi dengan berbagai macam aspek pendekatan dalam pemotretan. Hasil foto dari masing-masing fotografer yang berkolaborasi dengan peduduk yang difoto pasti akan berbeda-beda, baik dengan orang dewasa, remaja dan anak-anak. Strategi dalam pemotretan juga akan berbeda antara seorang fotografer dengan fotografer yang lain. Begitu pun jika seorang fotografer melakukan pemotretan dengan anak-anak, tentunya fotografer mempunyai cara tersendiri agar anak-anak bisa diarahkan saat dilakukan pemotretan.

Menurut Sugiarto (2005:10), pemotretan anak untuk tujuan komersial mempunyai tingkat kesulitan yang lebih tinggi. Adanya perkembangan emosional pada anak-anak bisa menjadi salah satu faktornya. Anakanak mampu mengekspresikan emosional yang ada dalam diri mereka. Ceria, tertawa, merajuk, menangis, pendiam, cerewet, itu semua adalah beberapa ekspresi emosi yang dimiliki oleh anak-anak. Bukan hal yang mengejutkan, jika emosional anak-anak membuat beberapa fotografer menghindari pemotretan dengan anak-anak karena perilaku 
yang susah diatur dan suasana hati mereka yang tidak teratur.

Berdasarkan latar belakang di atas, maka terdapat dua rumusan ide, yaitu pertama, bagaimana cara Roy Genggam dalam mengatasi kendala yang khas pada anak-anak saat pemotretan iklan Cussons dan kedua. Dua, bagaimana strategi kreatif Roy Genggam dalam pemotretan iklan Cussons. Dari kedua rumusan masalah tersebut perlu dilakukan tinjauan pustaka terhadap tulisan yang berkaitan dengan permasalahan yang diteliti dengan tujuan, agar tidak terjadi tumpang tindih dengan penelitian sebelumnya. Ada beberapa penelitian, buku maupun artikel dengan tema yang hampir sama dengan penelitian ini, antara lain pertama, artikel yang ditulis oleh Wahyu Dian pada e-Book (buku elektronik) APFIMAGZ dengan judul Genggam Idealis Roy (2016: 53-59). Kedua, penelitian yang dilakukan Pujiyanto pada e-journal (jurnal elektronik) dengan judul The Plundering of Child in Advertising Ethical Code Breaking (2014). Ketiga, Penelitian yang ditulis Nalendra Adimas Putra pada tahun 2015, mahasiswa Jurusan Desain Komunikasi Visual, Fakultas Seni Rupa, Institut Seni Indonesia Yogyakarta dengan judul penelitian Analisa Strategi Kreatif dengan Pendekatan Teori Visual Branding Marty Neumier (Studi Kasus Waralaba Coffe Shop "Coffe Toffe Surabaya” Tahun 2014). Keempat, penelitian yang ditulis Aswan Tatra, mahasiswa Jurusan Desain Komunikasi Visual, Fakultas Seni Rupa, Institut Seni Indonesia dengan judul penelitian Studi Proses Kreatif Produksi Iklan TV Komersial (2004). Kelima, penelitian yang ditulis Alit Ayu Dewantari mahasiswi Pascasarjana Program Penciptaan dan Pengkajian Seni, Pascasarjana Institut Seni Indonesia Yogyakarta dengan judul penelitian Strategi Kreatif Buku Pop-Up Sebagai Medium Komunikasi Visual (2015).

\section{METODE PENELITIAN}

Untuk mengetahui cara dalam mengatasi kendala yang khas pada anakanak saat pemotretan berlangsung dan strategi kreatif dalam suatu pemotretan, maka diperlukan wawancara serta studi dokumen dan arsip dalam mengumpulkan data. Metode tersebut digunakan karena penelitian ini mengkaji strategi kreatif Roy Genggam dalam suatu pemotretan dimana pemotretan tersebut sudah dikerjakan oleh Roy Genggam beserta tim RGP (Roy Genggam Photography). Dengan demikian penelitian ini adalah penelitian kualitatif dengan bentuk penyajian deskriptif atas fakta-fakta yang ditemukan. Moleong (2007:11) menambahkan, data yang dikumpulkan dari penyajian deskriptif adalah berupa kata-kata, gambar, dan bukan angka-angka.

Moleong (2007:6) menjelaskan, penelitian kualitatif bermaksud untuk memahami fenomena tentang apa yang dialami oleh subjek penelitian misalnya perilaku, persepsi, tindakan, dan lain-lain secara holistik, dan dengan cara deskripsi dalam bentuk kata-kata dan bahasa, pada suatu konteks khusus yang alamiah dan dengan memanfaatkan berbagai metode alamiah. Sebelum proses penelitian dilakukan perlu diketahui dulu variabel penelitian, setelah mengetahui variabel penelitian maka akan dilakukan pengumpulan data, sesudah data terkumpul perlu dilakukan analisis data. Inti analisis data terletak pada tiga proses yang berkaitan, yaitu mendeskripsikan fenomena, mengklasifikasikannya, dan melihat bagaimana konsep-konsep yang muncul itu satu dengan lainnya berkaitan (Dey dalam Moleong, 2007:289).

Pembahasan dalam penelitian ini adalah tentang strategi kreatif dalam pemotretan iklan salah satu produk yang peduduknya adalah anak-anak. Pemotretan tersebut sudah dikerjakan oleh Roy Genggam beserta tim RGP. 
Sehingga variabel operasional yang menjadi inti dari penelitian ini adalah strategi kreatif dan anak-anak.

Sehubungan dengan hal tersebut, maka akan didefinisikan masing-masing variable operasional. Yang pertama adalah strategi kreatif, yang dimaksud dalam penelitian ini adalah strategi kreatif Roy Genggam dalam pemotretan. Unsur-unsur yang meliputi strategi kreatif dalam pemotretan antara lain, peralatan fotografi yang digunakan, teknik fotografi, crew, objek pemotretan dan properti. Variabel kedua adalah anak-anak. Anak-anak yang dimaksud dalam penelitian ini adalah anakanak yang terlibat sebagai peduduk dalam pemotretan iklan suatu produk. Penelitian ini akan mengidentifikasi kendala yang khas pada anak-anak berdasarkan perubahan ekspresi emosi dan kepekaan diri. Tujuan dari didefinisikan setiap variabel tersebut untuk memudahkan dalam menentukan data yang dikumpulkan dan yang dianalisis.

Pengambilan sampel dalam penelitian ini ditentukan berdasarkan jumlah peduduk anak-anak dan tahun pembuatan foto. Sampel yang dipilih yaitu sesi pemotretan iklan suatu produk dengan jumlah peduduk paling sedikit dan paling banyak dalam satu frame foto. Ada pun alasan dipilihnya peduduk anakanak karena perlunya pengetahuan bagi seorang fotografer khususnya fotografer yang akan menekuni bidang foto komersial dalam menghadapi anak-anak saat pemotretan. Hal tersebut mungkin tidak ada kaitannya dengan teknis fotografi namun pengaruhnya cukup besar terhadap hasil akhir. Alasan dipilihnya jumlah peduduk paling sedikit dan paling banyak dalam satu frame karena untuk mengetahui tingkat kesulitan dalam pemotretan, apakah dengan jumlah peduduk sedikit mempunyai tingkat kesulitan yang sama dengan jumlah peduduk yang banyak.

Sampel juga ditentukan berdarkan tahun pembuatan foto terbaru. Alasan menentukan sample berdasarkan hal tersebut karena menurut anggapan seseorang, bahwa suatu kejadian yang baru terjadi dan banyak menghadapi masalah lebih teringat secara detail dari pada kejadian yang sudah lama terjadi dan tidak ada masalah. Anggapan tersebut didasarkan pada proses pembelajaran seseorang dalam menghadapi masalah.

\section{METODE PENGUMPULAN DATA}

Penelitian ini menggunakan beberapa metode pengumpulan data yang bertujuan untuk melengkapi bahan-bahan pelengkap data. Adapun beberapa metode tersebut, antara lain:

1. Wawancara

Menurut Keraf (2004:182), wawancara adalah suatu cara mengumpulkan data dengan mengajukan pertanyaan langsung kepada seorang informan. Wawancara langsung akan dilakukan dengan tiga narasumber antara lain produser RGP, salah satu asisten fotografer RGP, serta fotografer yaitu Roy Genggam. Perlunya dilakukan wawancara terhadap ketiga narasumber tersebut karena mereka dapat memberikan informasi-informasi yang terkait dalam penelitian ini.

Penelitian ini akan menggunakan wawancara terstruktur artinya pertanyaanpertanyaan yang akan disampaikan kepada narasumber sudah dipersiapkan sebelumnya. Namun tidak menutup kemungkinan bahwa pertanyaan-pertanyaan dalam wawancara langsung tersebut bisa berkembang. Untuk memperoleh data yang akurat, maka perlu diajukan pertanyaan-pertanyaan yang sama kepada ketiga narasumber. Pertanyaan yang sama tersebut mengenai kendala yang khas pada anak-anak dan cara mengatasi kendala tersebut. Roy Genggam sebagai fotografer dan asisten fotografer RGP dapat memberikan informasi tentang strategi kreatif dalam pemotretan, kendala yang 
khas pada anak-anak saat pemotretan berlangsung, dan memberi informasi tentang cara Roy Genggam dan tim RGP mengatasi kendala tersebut. Produser RGP dapat memberikan informasi tentang kendala yang khas pada anak-anak saat pemotretan berlangsung, dan memberi informasi tentang cara Roy Genggam dan tim RGP mengatasi kendala tersebut.

Jika data yang diperoleh dalam wawancara langsung masih belum lengkap, maka dapat dilakukan wawancara melalui komunikasi non-verbal. Komunikasi non-verbal dipakai karena keterbatasan waktu, jarak, dan biaya dalam melakukan wawancara langsung. Komunikasi non-verbal dapat dilakukan melalui surat elektronik dan media sosial seperti WhatsApp, Line, atau BBM.

\section{Studi Dokumen dan Arsip}

Melakukan pengumpulan data melalui dokumen visual atau foto dan arsip tertulis yang disimpan oleh Roy Genggam. Dokumen visual ini akan sangat membantu dalam pembahasan penelitian. Data dari dokumen visual didapati melalui hard disk yaitu media penyimpanan pada personal computer atau laptop. Metode ini digunakan saat menentukan sampel karya fotografi yang akan diteliti dan juga dapat menjadi pedoman narasumber dalam mengingat kembali proses pemotretan yang sudah berlalu atau sudah dikerjakan. Arsip tertulis yang disimpan oleh Roy adalah catatancatatan khusus tentang proses produksi atau eksekusi, mulai dari waktu, tempat, kendala yang terjadi dan bagaimana cara Roy Genggam mengatasi kendala tersebut.

\section{PEMBAHASAN}

Setiap fotografer pasti mempunyai impian dalam menciptakan sebuah karya atau memvisualkan sebuah gambar, namun tidak semua fotografer memiliki niat dalam mencapai impian tersebut. Jika ada seorang fotografer yang memiliki niat dalam mencapai impiannya, maka ia akan dihadapkan dengan berbagai situasi ketidakpastian. Adanya situasi ketidakpastian ini membuat seorang fotografer memiliki harapan, supaya ia mampu mengatasi ketidakpastian tersebut. Seorang fotografer akan melakukan berbagai cara agar harapannya tercapai, namun tidak semua cara-caranya berhasil. Ketika ada beberapa cara yang gagal, maka seorang fotografer akan berpikir dan menciptakan cara baru hingga harapan-harapannya bisa tercapai.

Berdasarkan hasil penelitian tersebut, hal yang dilakukan Roy Genggam merupakan bentuk kreativitas melalui cara berpikir serta pengalamannya (intuisi) dalam menghadapi suatu masalah. Intuisinya dalam menghadapi masalah tersebut membentuk suatu tindakan tertentu, salah satunya strategi (tindakan umum). Sementara Petty (1997) menjelaskan, jika masalah telah terpecahkan atau kesulitan telah teratasi, berarti kreativitas telah bekerja. Dari penjelasan tersebut dapat disimpulkan bahwa, kreativitas seorang fotografer dalam pemotretan tidak hanya ditentukan dari keberhasilan cara dalam mengatasi masalah, namun juga ditentukan dari adanya strategi dalam suatu pemotretan.

Intuisi setiap fotografer berbeda, antara satu fotografer dengan fotografer lainnya. Jika intuisi dalam mengahapi masalah pernah dilalui seorang fotografer dalam mewujudkan impian (rencana abstrak), maka strategi akan muncul. Strategi seorang fotografer muncul karena adanya situasi ketidakpastian dalam mencapai impian. Dari situasi ketidakpastian tersebut muncullah harapan fotografer agar dapat mengatasinya melalui cara-cara tertentu (tindakan khusus). Jika fotografer berhasil mengatasi masalahnya, maka fotografer tersebut adalah fotografer yang kreatif. Sebaliknya, jika seorang fotografer tidak berhasil mengatasi masalah, maka 
akan muncul intuisinya dalam menghadapi masalah. Intuisi tersebut akan membentuk strategi.

Strategi dari seorang fotografer dalam proses memotret bisa diterapkan ke dalam proses pemotretan yang dilakukan oleh fotografer lain. Akan tetapi tidak ada jaminan keberhasilan dalam menerapkan strategi tersebut. Hal tersebut merupakan salah satu kelemahan dari strategi. Sementara kelebihan dari strategi adalah mewujudkan suatu harapan dalam mencapai suatu impian (abstrak). Kelebihan tersebut muncul karena harapan terbentuk dari adanya situasi ketidakpastian. Dari penjelasan tersebut dapat dikatakan bahwa seseorang yang berusaha untuk mewujudkan harapan adalah orang yang kreatif.

Roy Genggam menggunakan 12 cara atau tindakan khusus dalam mengatasi kendala yang khas pada anak-anak saat pemotretan iklan Cussons. Keduabelas cara tersebut dibagi menjadi dua, yaitu cara yang dilakukan sebelum pemotretan dan cara yang dilakukan saat pemotretan. Adapun caracara tersebut antara lain:

A. Cara yang Dilakukan Sebelum Pemotretan 1. mencari tahu kebiasaan anak-anak sebelum hari pemotretan tiba

2. menjadwalkan pemotretan pada pagi hari

3. penyiapkan penggunaan dan pengaturan lampu studio sebelum anak-anak tiba di studio

4. penggunaan dan pengaturan lampu studio yang tidak rumit namun harus sesuai dengan target foto yang akan dibuat, dan

5. menyediakan mainan dan ruang bermain bagi anak-anak.

B. Cara yang Dilakukan Saat Pemotretan

1. mendekatkan diri dengan anak-anak ketika mereka sudah tiba di studio

2. memanfaatkan 30 menit pertama saat pemotretan dimulai
3. memutarkan lagu anak-anak di dalam studio

4. tidak memaksa anak-anak untuk difoto secara terus-menerus

5. membujuk anak-anak dengan snack yang mereka sukai

6. melibatkan orang tua dari masing anakanak saat pemotretan, dan

7. membuat situasi dan kondisi.

Cara-cara tersebut dilakukan Roy Genggam serta tim RGP sesuai arahannya dengan harapan, Roy Genggam mampu mengatasi kendala yang khas pada anak-anak saat pemotretan iklan Cussons.

Terdapat tiga tindakan umum atau strategi yang dilakukan Roy Genggam saat pemotretan iklan Cussons. Strategi tersebut antara lain, strategi anak-anak sebelum pemotretan, strategi anak-anak sesudah pemotretan, dan strategi hasil foto. Ketiga strategi ini perlu dilakukan Roy Genggam dan tim RGP sesuai dengan arahan Roy Genggam sebagai fotografer agar rencana memvisualisasikan layout (pemotretan) iklan Cussons bisa tercapai.

Strategi anak-anak sebelum pemotretan dan strategi anak-anak saat pemotretan merupakan dua tindakan umum yang dilakukan Roy Genggam dan tim RGP dalam mengatasi kendala yang khas pada anak-anak saat pemotretan iklan Cussons. Strategi ini muncul karena adanya respon dari suatu ketidakpastian dalam mengatasi terjadinya kendala yang khas pada anak-anak saat pemotretan iklan Cussons. Cara-cara dalam menerapkan strategi anak-anak bukan suatu keharusan untuk dilakukan. Namun strategi ini perlu dilakukan dengan harapan, Roy Genggam mampu mengatasi kendala yang khas pada anak-anak saat pemotretan iklan Cussons, walaupun tidak ada jaminan keberhasilan dalam menerapkan kedua strategi tersebut. Terjadinya kerja sama yang baik 
antara anak-anak dengan Roy Genggam serta tim RGP menjadi indikator keberhasilan dalam menerapkan strategi anak-anak.

Strategi hasil foto merupakan tindakan umum yang dilakukan Roy Genggam dan tim RGP dalam memprediksi pilihan foto yang dilakukan oleh klien pascapemotretan iklan Cussons. Strategi ini muncul karena adanya respon dari suatu ketidakpastian dalam memprediksi pilihan foto yang dilakukan oleh klien pascapemotretan iklan Cussons. Cara-cara dalam menerapkan strategi hasil foto bukan suatu keharusan untuk dilakukan. Namun startegi ini perlu dilakukan dengan harapan, Roy Genggam mampu memprediksi pilihan foto yang dilakukan oleh klien pascapemotretan iklan Cussons, walaupun tidak ada jaminan keberhasilan dalam menerapkan strategi hasil foto. Terjadinya mutilasi tubuh saat proses olah digital menjadi indikator keberhasilan strategi ini.

\section{KESIMPULAN DAN SARAN}

Setelah mengetahui tindakan umum dan tindakan khusus yang dilakukan Roy Genggam serta tim RGP, maka hasil penelitian tersebut dapat disimpulkan bahwa aspek nonteknis fotografi merupakan salah satu faktor keberhasilan dalam pemotretan iklan yang menggunakan anak-anak sebagai peduduk. Hal tersebut terjadi karena aspek teknis fotografi yaitu alat yang digunakan dan teknik fotografi dalam pemotretan iklan dipengaruhi oleh aspek nonteknis. Artinya bahwa aspek teknis fotografi mengikuti tindakan-tindakan yang dilakukan Roy Genggam yang berkaitan dengan aspek nonteknis fotografi. Walaupun demikian, aspek nonteknis fotografi juga berpengaruh terhadap hasil foto atau hasil akhir dalam suatu pemotretan. Sehingga, aspek non teknis fotografi sangat menentukan berhasil atau tidaknya seorang fotografer dalam pemotretan iklan yang menggunakan anak-anak sebagai peduduk.
Penggunaan metode pengumpulan data yang tepat, serta teknik dalam menggunakan metode tersebut merupakan salah satu hal yang menunjang dalam proses penelitian ini. Selain itu, ada beberapa hal yang menghambat selama proses penelitian, yaitu jarak yang jauh antara peneliti dan objek penelitian, kurangnya pendetakan terhadap narasumber dan tidak mempertimbangkan pemilihan sample bersama fotografer.

Terdapat tiga saran untuk para peneliti selanjutnya yang ingin melakukan penelitian atau mengembangkan penelitian dengan topik yang hampir sama khususnya dalam bidang fotografi. Ketiga saran ini muncul karena adanya hambatan-hambatan yang terjadi selama proses penelitian. Ketiga saran tersebut antara lain, pertama memilih objek penelitian yang mudah dijangkau. Jika keberadaan objek penelitian jauh dengan peneliti, maka perlu dipertimbangkan segala biaya yang dibutuhkan selama proses penelitian. Kedua, melakukan pendekatan terhadap narasumber sebelum dilakukan wawancara saat pengumpulan data. Ketiga, mempertimbangkan pemilihan sample bersama fotografer atau orang yang menciptakan karya tersebut. Setiap seniman atau praktisi yang menciptakan sebuah karya tentu mempunyai idealisme terhadap karya tersebut. Untuk itu ketika seorang peneliti ingin mengkaji karya atau proses dari pembuatan karya maka perlu mempertimbangkan pemilihan sample. Hal tersebut akan berdampak pada proses pengumpulan data (wawancara) yaitu perilaku narasumber (fotografer atau seniman) yang antusias atau tidak antusias.

\section{KEPUSTAKAAN}

\section{Buku}

Drewniany \& Jewler. Creative Strategy in Advertising. NP, Content Technologies: Textbook Reviews, 2015. 
Genggam, Roy. Memotret Pemotret. Tangerang: Pustaka Asri, 2015.

Hetherington, E. Mavis \& Ross D. Parke. A Contemporary Viewpoint $5^{\text {th }}$ Edition. USA, Boston: Mc Graw-Hill Collage, Inc. 1999.

Keraf, Gorys. Komposisi. Semarang: Bina Putera, 2004.

Moleong, Lexy J. Metodologi Penelitian Kualitatif. Bandung: PT Remaja Rosdakarya, 2007.

Munandar, S.U.C. Pengembangan Kreativitas Anak Berbakat. Jakarta: Rineka Cipta. 2009.

Petty, Geoffrey. How to be Better at .. Creativity = Memaksimalkan Potensi Kreatif. Jakarta: Elex Media Komputindo, 1997.

Santrock, John W. Life-Span Development $5^{\text {th }}$ Edition, terjemahan Juda Damanik \& Achmad Chusairi, editor Herman Sinaga \& Yati Sumiharti. Jakarta: Erlangga, 2002.

Soedjono, Soeprapto. Pot-Pourri Fotografi. Jakarta: Universitas Trisakti, 2007.

Souders, Rick. The Art and Attitude of Commercial Photography. New York: Amphoto Books, 2002.

Sugiarto, Atok. Memotret Anak-anak: Buku Pegangan Fotografi Manual/ Digital. Jakarta: PT Gramedia Pustaka Utama, 2005.

\section{Jurnal Penelitian}

Dewantari, Alit Ayu. Strategi Kreatif Buku Pop-Up Sebagai Medium Komunikasi Visual. Yogyakarta: Pascasarjana ISI Yogyakarta. 2015.

Pujiyanto. The Plundering of Child in Advertising Ethical Code Breaking. E-Journal: Malang State University, 2014.

Putra, Nalendra A. Analisa Strategi Kreatif dengan Pendekatan Teori Visual Branding Marty Neumier (Studi Kasus Waralaba Coffe Shop "Coffe Toffe Surabaya”. Yogyakarta: FSR ISI Yogyakarta, 2014.

Tatra, Aswan. Studi Proses Kreatif Produksi Iklan TV Komersial. Yogyakarta: FSMR ISI Yogyakarta, 2014.

\section{Pustaka Laman}

www.unmmyanmar.com (diakses pada 17 Oktober 2016)

www.roygenggam photography.com (diakses pada 6 Oktober 2016)

\section{Daftar Informan}

Pak De Solichin, Asisten Fotografer. Wawancara. Tangerang Selatan: 2024 Desember 2016.

Roy Genggam, Fotografer. Wawancara. Tangerang Selatan: 12-14 November 2016.

Tangerang Selatan: 20-24 Desember 2016.

Sari Ardaningsih (Ria), Asisten Produser. Wawancara. Tangerang Selatan: 2024 Desember 2016. 